Jurnal Keperawatan Silampari

Volume 4, Nomor 1, Desember 2020

e-ISSN: 2581-1975

p-ISSN: 2597-7482

DOI: https://doi.org/10.31539/jks.v4i1.1771

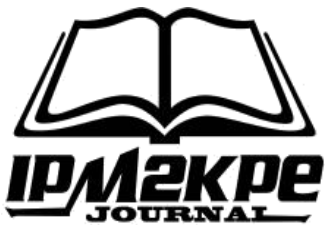

\title{
TERAPI OKUPASI MEMASANG TALI SEPATU TERHADAP MOTORIK HALUS PADA ANAK TUNAGRAHITA SEDANG
}

\author{
Mochamad Heri ${ }^{1}$, Ni Made Dwi Yunica Astriani ${ }^{2}$, Komang Gde Trisna Purwantara ${ }^{3}$, \\ Putu Devi Kurnia Sari ${ }^{4}$ \\ Sekolah Tinggi Ilmu Kesehatan Buleleng ${ }^{1,2,3,4}$ \\ mochamad_heri@rocketmail.com ${ }^{1}$
}

\begin{abstract}
ABSTRAK
Tujuan dari penelitian ini adalah untuk mengetahui pengaruh terapi okupasi memasang tali sepatu terhadap peningkatan kemampuan motorik halus pada anak tunagrahita di SLB N 1 Badung. Metode penelitian ini adalah penelitian kuantitatif dengan desain penelitian pra eksperimen pre-post test one group design. Hasil analisis univariat intervensi dari 41 responden sebelum diberikan terapi okupasi perkembangan motorik halus adalah 1.20 dan stelah diberikan terapi okupasi perkembangan motorik halus adalah 1.41. Hasil penelitian ini menunjukan rata-rata perkembangan motorik halus saat pre test adalah 1.20. Setelah diberikan perlakuan terapi okupasi memasang tali sepatu diperoleh rata-rata perkembangan motorik halus menjadi 1.41. Hasil analisa data dengan uji Wilcoxon dapatkan nilai 0,003 atau $p<\alpha(0,05)$. Simpulan, terdapat pengaruh antara terapi okupasi memasang tali sepatu terhadap motorik halus pada anak tunagrahita sedang Di SLB N 1 Badung.
\end{abstract}

Kata Kunci : Motorik Halus, Terapi Okupasi, Tunagrahita

\section{ABSTRACT}

The purpose of this study was to determine the effect of occupational therapy on attaching shoelaces to the improvement of fine motor skills in mentally disabled children in SLB $N 1$ Badung. This research method is quantitative research with preexperimental research design pre-post test one group design. The result of univariate analysis of the intervention of 41 respondents before being given occupational therapy for fine motor development was 1.20, and after being given occupational therapy, fine motor development was 1.41. The results of this study showed the average fine motor development during the pre-test was 1.20. After being given the occupational therapy treatment of attaching shoelaces, the average fine motor development was 1.41. Data analysis results with the Wilcoxon test get a value of 0.003 or $p<\alpha$ (0.05). In conclusion, occupational therapy influences placing shoelaces on fine motor skills in children with moderate mental retardation in SLB N 1 Badung.

Keywords: Fine Motoric, Occupational Therapy, Impairment 


\section{PENDAHULUAN}

Perkembangan adalah bertambahnya kemampuan struktur dan fungsi tubuh yang lebih kompleks, dalam pola yang teratur yang dapat diramalkan, sebagai hasil dari proses pematangan atau maturitas. Anak merupakan dambaan setiap keluarga. Selain itu setiap keluarga juga mengharapkan anaknya kelak bertumbuh kembang secara optimal. Dapat dibanggakan serta berguna bagi nusa dan bangsa. Anak adalah individu yang unik, yang masih bergantung pada orang dewasa dalam memenuhi kebutuhan dasarnya (Heri \& Ariana 2018).

Perkembangan pada anak meliputi beberapa aspek, salah satunya yaitu aspek fisik motorik. Fisik secara bahasa diartikan sebagai tubuh, jasmani, dan badan. Sedangkan motorik diartikan dengan penggerak (Padila et al., 2019). Jadi perkembangan fisik motorik anak usia prasekolah dapat diartikan sebagai perubahan bentuk tubuh pada anak usia prasekolah yang berperngaruh terhadap keterampilan gerak (Madyastuti, 2016). Kemampuan motorik halusanak usia prasekolah mulai berkembang dimana anak mulai dapat mengunakan jari-jarinya untuk menulis, menggambar dan lain-lain. Proses tahapan perkembangan setiap anak sama, yaitu merupakan hasil dari proses pematangan organ motorik. Tetapi dalam pencapaiannya, setiap anak memiliki kecepatan yang berbeda-beda.

Retardasi mental atau tunagrahita adalah istilah yang digunakan untuk menyebut anak yang mempunyai kemampuan intelektual di bawah rata - rata. Selain itu ada beberapa kondisi yang terjadi pada anak yang mengalami retardasi mental. Anak retardasi mental sangat sulit untuk belajar membaca, menulis dan berhitung walaupun mereka masih dapat menulis namanya sendiri tetapi untuk pertanyaan berulang tidak dapat dijawab dengan baik oleh anak dengan retardasi mental (Wardana et al., 2020).

Anak tunagrahita merupakan anak yang memiliki tingkat kecerdasan intelektual rendah. Siswa tunagrahita ringan mampu menguasai sebagian besar kosakata dasar yang ada dalam daftar kosakata Swadesh yang berjumlah 200 ko-sakata dasar (Pandudinata et al., 2018).

Tumbuh kembang merupakan manifestasi yang kompleks dari perubahan morfologi, biokimia, dan fisiologi yang terjadi sejak konsepsi sampai maturase/dewasa. Banyak orang menggunakan istilah "tumbuh" dan "kembang" secara sendiri-sendiri atau bahkan ditukar-tukar. Istilah tumbuh kembang sebenarnya mencakup dua peristiwa yang sifatnya berbeda, Tetapi saling berkaitan dan sulit dipisahkan yaitu pertumbuhan dan perkembangan (Sundayana et al., 2020).

Berdasarkan data dari Internasional Labour Organization dimana $82 \%$ dari jumlah penyandang disabilitas di dunia berada di kalangan Negara berkembang. Sedangkan hasil survei dari ILO di Indonesia pada tahun 2015 menyebutkan bahwa jumlah penyandang disabilitas mencapai $10 \%$ dari jumlah penduduk Indonesia, sedangkan jumlah penyandang disabilitas mental mencapai 1.389.614 jiwa. Di Bali jumlah penyandang tunagrahita mencapai 2.754 jiwa pada tahun 2017 , sedangkan di Kabupaten Badung jumlah penyandang tunagrahita yang terdata mencapai 202 jiwa pada tahun 2017 (Dinas Sosial, 2017).

Dukungan orang tua menjadi hal yang sangat penting dalam tumbuh kembang anak dengan retardasi mental. Ruliati (2020) menyatakan bahwa Orang Tua berperan dalam memberikan pengarahan, memberikan motivasi kepada anak ketika menghadapi masalah, menjadi panutan untuk anak, dan orang tua memberikan dukungan terhadap prestasi anak. Adanya pemberian dukungan orang tua melalui interaksi yang 
dikembangkan orang tua yang dicirikan oleh perawatan, persetujuan, dan berbagai perasaan positif orang tua terhadap anak.

Penanganan umum pada anak retardasi mental adalah masalah pendidikan, edukasi, dan latihan. Bentuk latihan atau terapi yang sering diajarkan untuk anak retardasi mental antara lain seperti terapi perilaku, terapi bermain, dan terapi okupasi. Terapi yang paling cocok digunakan dalam mengatasi masalah dalam merawat diri dari ketiga terapi tersebut adalah dengan terapi okupasi (Rokhman \& Rohmah, 2019).

Terapi ini sangat membantu mereka untuk berlatih menggerakkan tubuhnya. Banyak cara yang dapat dilakukan pada terapi okupasi untuk meningkatkan koodinasi gerak, misalnya dalam kemampuan motorik halus seperti meremas, menempel, meronce, menulis, mewarnai gambar, memasang tali sepatu, memasang kancing baju. Hasil penelitian yang dilalukan oleh Rokhman \& Rohmah (2019) menunjukkan bahwa Terapi Okupasi memiliki pengaruh yang signifikan terhadap tingkat kemandirian merawat diri pada anak retardasi mental. Sejalan dengan penelitian Padila et al., (2019) terdapat pengaruh yang signifikan antara skor tahap perkembangan pada kelompok dengan stimulasi DDST dan SDIDTK sebelum dilakukan dengan setelah dilakukan intervensi.

Hasil penelitian yang dilakukan oleh Pradipta \& Dewantoro, (2019); Panzilion et al., (2020) hasil penelitiannya melakukan terapi okupasi dengan pada anak tuna grahita melalui origami dan kobinasi puzlle angka serta buah. Kegiatan bermain ini mampu melatih keterampilan menggerakkan jari, keterampilan menggerakan pergelangan tangan, dan keterampilan menggerakkan lengan. Oleh karena itu, ada sepuluh manfaat origami, yaitu; 1) pembentukan keterampilan motorik yang lebih sempurna di kedua tangan; 2) meningkatkan kemampuan intelektual; 3) meningkatkan kemampuan daya kreatif; 4) merangsang kinerja yang seimbang antara bagian otak kiri dan kanan; 5) meningkatkan imajinasi; 6) meningkatkan kemampuan untuk memusatkan perhatian (bisa dibilang meningkatkan konsentrasi); 7) peningkatan kapasitas memori (memory); 8) kesabaran; 9) memberikan pengalaman emosional dan estetika, dan tentu saja; 10) memungkinkan seseorang untuk lebih menghargai kesenangan, kepuasan, dan kebanggaan dalam pekerjaannya. Sesuai dengan manfaatnya, origami dapat membantu siswa tunagrahita untuk melatih dan meningkatkan kemampuan motorik halusnya.

Kelompok orang tua yang memiliki anak dengan retardasi mental sedang cenderung tidak terlalu terkejut ketika mengetahui kondisi anak secara resmi. Hal ini dikarenakan orang tua dengan anak retardasi mental sedang sudah melihat perbedaan anak semenjak dini disebabkan karena tumbuh kembangnya yang lebih lambat pada usianya dari anak lain (Dianna, 2019).

Oleh karena itu penelitian ini dilakukan dengan memberikan terapi okupasi. Kelebihan penelitian ini adalah penggunaan Terapi okupasi yang diberikan adalah dengan memasang tali sepatu. Masih terbatas penelitian tentang terapi okupasi dengan metode memasang tali sepatu. Dalam terapi ini anak akan dilatih untuk memasukkan tali ke dalam lubang dimana memasang tali sepatu dapat melatih motorik halus, karena yang biasanya digunakan dalam menalikan sepatu adalah jari telunjuk dan ibu jarinya sehingga seperti melatih jari-jemari. Koordinasi gerakan dengan pandangan juga dilatih sehingga tidak salah memasukkan tali. Berdasarkan uraian tersebut maka penelitian ini bertujuan untuk mengetahui pengaruh terapi okupasi memasang tali sepatu terhadap peningkatan kemampuan motorik halus pada anak tunagrahita di SLB N 1 Badung, Bali 


\section{METODE PENELITIAN}

Jenis penelitian ini adalah Pre Experimental dengan rancangan desain One Group Pre-test Post-test, dimana akan dilakukan pre-test terlebih dahulu sebelum diberikan perlakuan, setelahnya akan diberikan perlakuan dan terakhir akan dilakukan post-test. Rancangan ini tidak ada kelompok pembanding (control), tetapi disini telah melakukan observasi pertama (pretest) yang akan memungkinkan mengukur perubahan - perubahan yang ada setelah dilakukannya eksperimen.

Populasi dalam penelitian ini adalah siswa/siswi SD penyandang tunagrahita sedang di SLB N 1 Badung sebanyak 46 orang dan Jumlah sampel dalam penelitian ini yaitu sebanyak 41 orang. Kriteria inklusi dalam penelitian ini adalah Anak tunagrahita kategori sedang dan berusia 10-15 tahun

Pelaksanaan Penelitian dilakukan pada bulan Mei - Juni 2020. Lokasi penelitian adalah di SLB N 1 Badung Propinsi Bali. SLB N 1 Badung beralamat di Jl. By Pass Ngurah Rai, Jimbaran, Kuta Selatan, Kabupaten Badung, Provinsi Bali

\section{HASIL PENELITIAN Analisis Univariat}

Tabel. 1

Distribusi Frekuensi Responden Berdasarkan Jenis Kelamin

\begin{tabular}{lcc}
\hline Jenis Kelamin & Frekuensi & Presentase (\%) \\
\hline Perempuan & 18 & 43.9 \\
Laki-laki & 23 & 56.1 \\
\hline Total & 41 & 100.0 \\
\hline
\end{tabular}

Berdasarkan tabel 1 dapat dilihat bahwa dari 41 responden sebagian besar responden dengan jenis kelamin laki-laki yaitu 23 responden $(56.1 \%)$ dan sebagian kecil dengan dengan jenis kelamin perempuan yaitu 18 responden $(43.9 \%)$.

Tabel. 2

Distribusi Responden

Berdasarkan Umur

\begin{tabular}{lccccc}
\hline & $\mathrm{N}$ & Mean & Min & Max & SD \\
\hline Usia & 41 & 13.20 & 11 & 15 & 1.123 \\
\hline
\end{tabular}

Berdasarkan tabel 2 menunjukan bahwa rata-rata umur anak tunagrahita yaitu 13.20 dari 41 responden dengan standar deviation 1.123 .

Tabel. 3

Skor Motorik Halus Sebelum Diberikan Terapi Okupasi Memasang Tali Sepatu

\begin{tabular}{cccccc}
\hline & $\mathrm{N}$ & Mean & Min & Max & SD \\
\hline Pre test & 41 & 1.20 & 1 & 2 & 0.401 \\
\hline
\end{tabular}

Berdasarkan tabel 3 menunjukan rata-rata nilai motorik halus sebelum diberikan terapi okupasi memasang tali sepatu adalah 1.20 dari 41 responden, dengan standar deviation 0.401 . 
Tabel. 4

Skor Motorik Halus Sesudah Diberikan

Terapi Okupasi

\begin{tabular}{lccccc}
\hline & $\mathrm{N}$ & Mean & Min & Max & SD \\
\hline Post test & 41 & 1.41 & 1 & 4 & 0.499 \\
\hline
\end{tabular}

Berdasarkan tabel 4 menunjukan rata-rata nilai motorik halus sesudah diberikan terapi okupasi memasang tali sepatu adalah 1.41 dari 41 responden, dengan standar deviation 0.499 nilai terendah 1 dan nilai tertinggi 4 .

\section{Analisis Bivariat}

Tabel. 5

Tabel Hasil Uji Wilcoxon Signed Rank Test

\begin{tabular}{ccc}
\hline & $\mathrm{Z}$ & $\mathrm{P}$ value \\
\hline Wilxocon Test & -3.000 & 0.003 \\
Pre test - Post test & & \\
\hline
\end{tabular}

Berdasarkan tabel 5 hasil analisis Uji Wilcoxon dapat dilihat dari nilai p yaitu 0,003 yang berarti $\mathrm{p}<0,05$, sehingga dapat disimpulkan ada pengaruh terapi okupasi memasang tali sepatu terhadap motorik halus anak tunagrahita sedang di SLB N 1 Badung.

\section{PEMBAHASAN}

\section{Analisis Univariat}

Berdasarkan tabel 1 dan tabel 2 dapat Dilihat dari hasil penelitian tentang karakteristik responden berdasarkan jenis kelamin dan umur di SLB N 1 Badung. Karakteristik responden berdasarkan umur menunjukan bahwa rata-rata umur anak tunagrahita yaitu 13.20 dari 41 responden dengan standar deviation 1.123, umur minimal anak tunagrahita adalah 11 tahun dan umur maksimal adalah 15 tahun. Sedangkan karakteristik responden berdasarkan jenis kelamin didapatkan bahwa responden dengan jenis kelamin laki-laki lebih besar yaitu sebanyak 23 responden (56.1\%) dan jenis kelamin perempuan lebih kecil sebanyak 18 responden (43.9\%).

Penelitian ini mendukung beberapa penelitian sebelumnya bahwa anak tunagrahita banyak terjadi pada anak tunagrahita berjenis kelamin laki-laki dibandingankan perempuan. Anak laki-laki cenderung mengalami gangguan psikologis lebih banyak dibandingkan anak perempuan. Kesulitan belajar lebih banyak dialami anak laki-laki, misalnya hambatan membaca, hambatan berhitung, dan hambatan menulis.

Berdasarkan tabel 3 menunjukan rata-rata nilai motorik halus sebelum diberikan terapi okupasi memasang tali sepatu adalah 1.20 dari 41 responden, dengan standar deviation 0.401 nilai terendah 1 dan nilai tertinggi 2. Sebelum pemberian perlakuan terapi okupasi memasang tali sepatu pada anak tunagrahita sedang di SLB N 1 Badung, terlebih dahulu peneliti melakukan komunikasi untuk menumbuhkan hubungan saling percaya antara anak tunagrahita dengan peneliti. Setelah itu peneliti melakukan penelitian terhadap tingkat motorik halus dengan menggunakan lembar observasi. 
Hasil penelitian ini menunjukan bahwa rata-rata anak yang mengalami tunagrahita sedang sebelum dilakukan memasang tali sepatu mempunyai kemampuan motorik halus yang kurang. Berdasarkan hasil penelitian ini dapat dijelaskan bahwa rata-rata anak yang mengalami tunagrahita sedang tidak mampu memasang tali sepatu sebanyak 33 responden dengan persentase $80.5 \%$ dan yang mampu memasang tali sepatu hanya 8 responden dengan persentase $19.5 \%$. Rata-rata nilai motorik halus sebelum diberikan terapi okupasi memasang tali sepatu adalah 1.20 dari 41 responden, dengan standar deviation 0.401 nilai terendah 1 dan nilai tertinggi 2. Pada penelitian ini perkembangan kemampuan motorik halus pada anak tunagrahita ringan sangat tergantung bagaimana cara kita membimbing, melatih, dan mengasah kemampuan motorik halus dari anak tunagrahita melalui kegiatan dan rangsangan yang kontinue secara rutin. Setelah dilakukan intervensi selama 1 bulan dengan 13 kali pertemuan kemampuan motorik halus pada anak tunagrahita ringan meningkat serta meningkatkan kemampuan berfikir dan kreatifitas dari anak tunagrahita ringan.

Berdasarkan tabel 4 menunjukkan rata-rata nilai motorik halus sesudah diberikan terapi okupasi memasang tali sepatu adalah 1.41 dari 41 responden, dengan standar deviation 0.499 nilai terendah 1 dan nilai tertinggi 4 . Setelah pemberian perlakuan terapi okupasi memasang tali sepatu pada anak tunagrahita sedang di SLB N 1 Badung selama 2 minggu dengan jumlah pertemuan $6 \mathrm{kali}$, peneliti melakukan penelitian terhadap motorik halus pada anak tunagrahita sedang dengan menggunakan lembar observasi.

Dilihat dari hasil penelitian ini menunjukan adanya peningkatan kemampuan motorik halus pada anak tunagrahita sedang sesudah dilakukan intervensi memasang tali sepatu. Intervensi yang dilakukan sebanyak 6 kali selama 2 minggu yang bertujuan melatih dan merangsang secara kontinue motorik halus dari anak tunagrahita sedang melalui terapi okupasi memasang tali sepatu. Berdasarkan hasil posttest pada 41 responden sebanyak 17 responden (41.5\%) dinyatakan mampu melakukan terapi okupasi memasang tali sepatu dan 24 responden (58.5\%) dinyatakan tidak mampu melakukan terapi okupasi memasang tali sepatu. Rata-rata nilai motorik halus sesudah diberikan terapi okupasi memasang tali sepatu adalah 1.41 dari 41 responden, dengan standar deviation 0.499 nilai terendah 1 dan nilai tertinggi 4.

Hasil penelitian ini sejalan dengan penelitian yang dilakukan oleh Pradipta \& Dewantoro, (2019); Panzilion et al., (2020) hasil penelitiannya melakukan terapi okupasi dengan pada anak tuna grahita melalui origami dan kobinasi puzlle angka serta buah. Kegiatan bermain ini mampu melatih keterampilan menggerakkan jari, keterampilan menggerakan pergelangan tangan, dan keterampilan menggerakkan lengan. Oleh karena itu, ada sepuluh manfaat origami, yaitu; 1) pembentukan keterampilan motorik yang lebih sempurna di kedua tangan; 2) meningkatkan kemampuan intelektual; 3) meningkatkan kemampuan daya kreatif; 4) merangsang kinerja yang seimbang antara bagian otak kiri dan kanan; 5) meningkatkan imajinasi; 6) meningkatkan kemampuan untuk memusatkan perhatian (bisa dibilang meningkatkan konsentrasi); 7) peningkatan kapasitas memori (memory); 8) kesabaran; 9) memberikan pengalaman emosional dan estetika, dan tentu saja; 10) memungkinkan seseorang untuk lebih menghargai kesenangan, kepuasan, dan kebanggaan dalam pekerjaannya. Sesuai dengan manfaatnya, origami dapat membantu siswa tunagrahita untuk melatih dan meningkatkan kemampuan motorik halusnya. 


\section{Analisis Bivariat}

Berdasarkan Tabel 5 menunjukkan Hasil analisis data dengan menggunakan Uji Wilcoxon Signed Rank Test menunjukan bahwa Asymptotic Significance yaitu $(0,003)$ yang berarti $\mathrm{p}<0,05$, maka $\mathrm{H}_{0}$ ditolak dan $\mathrm{H}_{\mathrm{a}}$ diterima, sehingga dapat disimpulkan ada pengaruh terapi okupasi memasang tali sepatu terhadap motorik halus anak tunagrahita sedang di SLB N 1 Badung.

Melihat pengaruh terapi okupasi memasang tali sepatu terhadap motorik halus pada anak tunagrahita sedang di SLB N 1 Badung dengan membandingan hasil rata-rata skor motorik halus sebelum dan sesudah intervensi terapi okupasi memasang tali sepatu diberikan. Hasil rata-rata (Mean) motorik halus sebelum diberikan intervensi terapi okupasi memasang tali sepatu adalah 1.20 dan setelah diberikan intervensi terapi okupasi memasang tali sepatu adalah 1.41 Pada penelitian ini membuktikan adanya pengaruh terapi okupasi memasang tali sepatu terhadap motorik halus anak tunagrahita sedang di SLB N 1 Badung.

Hal ini sejalan dengan penelitian Mahdalena et al., (2020), berdasarkan hasil penelitian dan pembahasannya dengan memberikan terapi okupasi dengan teknik menggunting diperoleh perbedaan skor anak saat pretest dan posttest, sehingga dapat disimpulkan bahwa terdapat pengaruh keterampilan menggunting terhadap kemampuan motorik halus anak autis kelas VIII di SLB Autis Laboratorium UM. Setelah penelitian dilaksanakan diketahui bahwa pengaruh keterampilan menggunting terhadap kemampuan motorik halus anak autis menunjukan adanya peningkatan mean level pada kemampuan motorik halus.

Penelitian yang dilakukan Jafri et al., (2019) menunjukkan bahwa Intervensi yang diberikan yaitu terapi okupasi bina diri yaitu suatu jenis terapi yang secara khusus digunakan untuk membantu anak untuk hidup mandiri dengan berbagai kondisi kesehatan yang telah ada dengan cara memberikan kesibukan atau aktivitas sehingga anak akan fokus untuk mengerjakan sesuatu. Hasil penelitianya menemukan bahwa rata-rata skor kemandirian responden sebelum intervensi adalah 85,92 dengan Standar deviation (SD) 18,36.Rata-rata skor kemandirian responden sesudah intervensi adalah 144,38 dengan Standar deviation (SD) 18,07.Uji statistik yang digunakan yaitu uji$\mathrm{T}$ (paired sample test) dengan $\mathrm{p} \leq \alpha(0,05)$, di dapatkan perbedaan rata-rata kemandirian responden antara sebelum dan sesudah intervensi dengan perbedaan ratarata 58,46 dan $\mathrm{p}=0,000$ dimana terjadi peningkatan kemandirian setelah intervensi dengan menggunakan terapi okupasi.

Terapi okupasi memasang tali sepatu melibatkan otot-otot kecil pada jari jemari tangan seperti ibu jari dan telunjuk serta koordinasi gerakan mata dan tangan agar tali sepatu tepat dimasukkan ke lubang sepatu. Anak memerlukan keterampilan melihat, mengingat dan mempraktekkan dalam mengembangkan keterampilan motorik halusnya, jika gerakan ini dilakukan berulang-ulang maka akan ada peningkatan pengembangan motorik halus pada anak tunagrahita sedang.

\section{SIMPULAN}

Karakteristik responden berdasarkan jenis kelamin menunjukan bahwa distribusi frekuensi mayoritas berjenis kelamin laki-laki dengan usia minimum yaitu 11 tahun dan usia maksimum yaitu 15 tahun. Berdasarkan hasil pengukuran motorik halus sebelum dilakukan terapi okupasi memasang tali sepatu diketahui bahwa sebagian besar anak tidak mampu memasang tali sepatu. Sedangkan, pengukuran sesudah dilakukan terapi okupasi memasang tali sepatu diketahui bahwa sebagian besar anak mampu memasang 
tali sepatu. Berdasarkan uji analisa data dengan menggunkaan uji Wilxocon menunjukan ada pengaruh yang signifikan antara terapi okupasi memasang tali sepatu terhadap motorik halus anak tunagrahita sedang di SLB N 1 Badung.

\section{SARAN}

Hasil penelitian ini diharapkan dapat digunakan untuk mengembangkan materi tentang tumbuh kembang anak dalam pendidikan keperawatan, menambah referensi perpustakaan dan informasi acuan profesi keperawatan serta institusi dalam pelaksanaan pengembangan kemampuan motorik halus anak.

Dapat juga digunakan sebagai data dalam melakukan penelitian dan mampu memberikan pedoman atau bahan pertimbangan untuk mengenbangkan penelitian di bidang keperawatan yang berkaitan dengan perkembangan motorik halus anak dengan variabel, metodologi dan sampel yang berbeda.

Penelitian ini diharapkan dapat dijadikan pedoman dalam pengembangan kemampuan motorik halus pada anak sehingga dapat mengoptimalkan kemampuan motorik halus anak di SLB N 1 Badung.

\section{DAFTAR PUSTAKA}

Dianna, A. M. (2019). Komunikasi Orang Tua Untuk Mengurangi Ketidakpastian Pada Anak Retardasi Mental. Interaksi Online, 7(4), 1-12. https://ejournal3.undip.ac.id/index.php/interaksi-online/article/view/24763

Dinas Sosial. (2017). DATA PACA 2017.

Heri, M., \& Ariana P. A. (2018). Pengaruh Media Flashcard terhadap Kemampuan Kognitif Anak Usia 3-4 Tahun di Tpa Yayasan Pantisila Paud Santo Rafael Singaraja. Midwinerslion: Jurnal Kesehatan StiKes Buleleng, 3(2), 3-4. https://ejournal.stikesbuleleng.ac.id/index.php/Midwinerslion/article/view/18

Jafri, Y., Nabella, E. P., \& Nofriadi, N. (2019). Terapi Okupasi Bina Diri Terhadap Kemandirian Pada Anak Tunagrahita. Prosiding Seminar Kesehatan Perintis, 2(1), 105-110. https://jurnal.stikesperintis.ac.id/index.php/PSKP/article/view/381

Madyastuti, L. F. R. (2016). Pengaruh Terapi Bermain Puzzle terhadap Perkembangan Motorik Halus dan Kognitif Anak Usia Prasekolah (4-5 Tahun). Journal of Ners Community, 7(2), 136-148

Mahdalena, R., Shodiq, M., \& Dewantoro, D. A. (2020). Melatih Motorik Halus Anak Autis Melalui Terapi Okupasi. Jurnal Ortopedagogia, 6(1), 1-6. http://journal2.um.ac.id/index.php/jo/article/view/9320

Padila, P., Andari, F. N., \& Andri, J. (2019). Hasil Skrining Perkembangan Anak Usia Toddler antara DDST dengan SDIDTK. Jurnal Keperawatan Silampari, 3(1), 244-256. https://doi.org/10.31539/jks.v3i1.809

Pandudinata, R., Sumarlam, S., \& Saddhono, K. (2018). Pemerolehan Bahasa Siswa Tunagrahita Kelas Vi Sd. RETORIKA: Jurnal Bahasa, Sastra, dan Pengajarannya, 11(1), 48. https://doi.org/10.26858/retorika.v11i1.4988

Panzilion, P., Padila, P., Amin, M., \& Andri, J. (2020). Perkembangan Motorik Prasekolah antara Intervensi Brain Gym dengan Puzzle. Jurnal Keperawatan Silampari, 3(2), 510-519. https://doi.org/https://doi.org/10.31539/jks.v3i2.1120

Pradipta, R. F., \& Dewantoro, D. A. (2019). Origami and Fine Motoric Ability of Intellectual Disability Students. International Journal of Innovation, Creativity and Change, 5(5), 531-545. https://www.semanticscholar.org/paper42dae57d4 
Rokhman, A., \& Rohmah, F. (2019). Mental dengan Terapi Okupasi di SDLB Negeri Lamongan. Jurnal Ilmiah Keperawatan, 5(2), 92-98. https://doi.org/https://doi.org/10.33023/jikep.v5i2.239

Ruliati, R. (2020). Dukungan Orang Tua terhadap Fungsi Sosial pada Anak Retardasi Mental. Jurnal Kesehatan "Samodra Ilmu," 11(2), 200-208. https://stikesyogyakarta.e-journal.id/JKSI/article/view/123

Sundayana, I., Aryawan, K., Fransisca, P., \& Astriani, N. M. (2020). Perkembangan Motorik Halus Anak Usia Pra Sekolah 4-5 Tahun dengan Kegiatan Montase. Jurnal Keperawatan Silampari, 3(2), 446-455. https://doi.org/https://doi.org/10.31539/jks.v3i2.1052

Wardana, K. E. L., Suarmini, K. A., Sugiartini, D. K., \& Wahyuni, N. K. E. (2020). Terapi Bermain Bagi Tuna Grahita Di Slb Negeri 2 Singaraja Bali. Jurnal Peduli Masyarakat, 2(2), 65-72. https://doi.org/https://doi.org/10.37287/jpm.v2i2.112 